\title{
Mentoring and Career Development of Academics in Colleges of Education in Cross River State Nigeria
}

\author{
$\mathrm{PhD}$ Florence A. Undiyaundeye \\ Department of psychology, Federal College of Education Obudu \\ Julius. A Basake \\ Obanliku Local Government Educational Authority Sankwala
}

\begin{abstract}
Currently the reasons for mentoring in our career is on the increase as the operational environment is embedded with risk, change ,staff competition, unethical career practices, high uncertainty, unfavourable government policy implementation and ignorance of the role of mentors being in control of the weak site. It is grossly required for good mentoring to be in our educational system of rewards and promotion. The study therefore investigates mentoring and career development of academia in colleges of education in Cross River state, Nigeria. A descriptive survey research design was adopted for the study. The population for the study comprised all the 1075 Chief lecturers and young lecturers 'while multi choice sampling technique was used to sample 570 respondents. One research question and two research hypotheses guided the study. The researcher developed questionnaires tagged 'Mentoring and Career Development for Academia Questionnaire' (MCDAQ). Questionnaire containing 12 items was the instrument for data collection, which was validated by three experts from the University of Calabar, Calabar with total reliability coefficients of 0.82 . Mean ratings and standard deviation were used in answering the research questions. While $T$ test was used in testing the hypothesis. The major findings of the study revealed that mentoring is in practices in collages of education in Cross River state, Nigeria. That there is mentoring relationships among academic staff. The study also revealed that female face more challenges in course mentoring than the male academic
\end{abstract}

Keywords: Mentoring, Career development, Career experience re- orientation, and Career openness

\section{Introduction}

The world today is in a state of flux and there has been an incredible pressure on human resource managers to meet up with the continuous changing environment, most especially as it relates to human resource in academics in colleges of education in Nigeria. The cardinal objective of Colleges of Education in Nigeria is to prepare the will-be teachers in areas of teaching, research, community development. (NCCE,2015) For the above objective to be achieved the human resource (academia) must be properly harnessed. It is in this light that Spencer, C. (2010) emphasized that the effectiveness of a college or university is directly linked to the quality and vigour of its faculty members. Today's conditions of limited resources and ever-increasing demand for accountability have made the optimum performance of a college a top priority in higher education.

Colleges career development is recognized as an important factor in maintaining colleges vitality (Ugwuanyi, RNC 2011). Career development and advancement are believed to be influenced by a variety of personal characteristics; however, evidence suggests that environmental and organizational factors also play a significant part in the academic career development process (Baugh \& Sullivan, 2005) One of such factors is that of mentoring. "Today one can make mention of mentoring in almost every publication aimed at management, administrators, educators, human resource professionals, and the general public" (Okurame, (2006);

Mentoring is a very old concept in a new guise. It can be traced back to Greek mythology when Odysseus entrusted his son Telemachus to the Goddess Athena, who disguised herself in human form as a mentor and old friend of Odysseus. Her function, according to Ezenwa (2011) was to act as a wise counsellor and helper to the youths. Mentoring then became 
common practice in the time of the guild and trade apprenticeships when young people, having acquired technical skills, often benefited from the patronage of more experienced and established professional. Most successful people in any walk of life probably have had one or more people over the years who have established particularly a strong influence over their lives and careers.

Mentoring therefore can be seen as a deliberate coupling of a more skilled or experienced one with the agreed-upon goal of having the less experienced person grow and develop specific competencies (Murry and Owen 2002). Also, mentoring according to Olowu A. (2013) connotes an assistance given to an individual in other to enable him/her grow in the profession. In the same vein, Young A. M, Cady, S. and Forom M. I (2006) define mentoring as a relationship which exists between the mentor (principals) and the mentee (subordinates) with the aim of assisting the mentee to cope with a new situation like a new job or a change in personal circumstances or in career development.

Barth R. (2011) defined mentorship as a process of informal transmission of knowledge, social capital and the psychosocial support perceived by the recipient as relevant to work, career, or professional development which entails informal communication, usually face to face and during a sustained period of time, between a person who is perceived to have greater relevant knowledge, wisdom or experience (the mentor) and the person perceived to have less (the mentee). By this definition, mentoring is a process which involves time, helping, personal development and relationship between an expert which in this study is principals in Imo state secondary schools and a neophyte being teachers and vice principals in Imo state secondary schools. The principals in this study as mentors are expected to give their expert knowledge so that their subordinates (vice principals and teachers) will develop their full potentials while in the teaching profession.

It is in this vein that Okurame, , (2006), noted that in Colleges of Education or Faculties the Professors or Chief Lecturers are the mentors while the newly employed lecturer ranging from Assistant to about Lecturer II are often subjected to mentorship, he further noted that other ranks of lecturers below the ranks of Professor and Chief Lecturer do it as self profession growth

The pursuit of development by young scholars in the Nigerian academic terrain is not without challenges, fears and anxieties. Indeed, Murray \& Owen,. (1991) suggests that youthful entrants into the adult workplace encounter a variety of developmental tasks that are effectively facilitated by a good mentor relationship. Mentoring is regarded as one of the best tools for "reducing stress for novice teachers, orientation to curriculum and promoting the creation of better norms of collegiality and collaboration" (Paynes, 2006). It helps in the resolution of challenges and predicaments, making it more likely that an individual attains his career goals and growth. The benefits of mentoring are based on a developmental social learning perspective which posits that behaviour is learned in interaction with others, especially when they serve as models (Dancer, J.A 2003). In this regard, mentoring is especially valuable for the transmission of positive attitudes as mentors provide invaluable information on the mission and philosophies of the organisation, help employees cope with career stress and give proper orientation towards workplace values ( Payne, 2006).

In addition, mentoring affords the transfer of skills which protégés can apply in diverse professional circumstances, promotes productive use of knowledge, clarity of goals and roles, career success, career growth, salary increases and promotions, career and job satisfaction (Okurame \& Balogun, 2005). Mentoring relationships are also useful even to the senior partner in the union, as it provides an opportunity for them to develop a base for technical support and power which can be readily summoned in the future (Okurame 2002). Being recognised as the mentor of a successful protégé enhances the reputation of the senior academic/partner among his or her peers. Obviously, the positive outcomes of mentoring are capable of fostering a satisfied and 'well-groomed' professional workforce. The corollary of the mentoring relationship can therefore be summed up as the professional development of employees and institutional effectiveness.

However true mentoring is more than just answering occasional questions or providing ad hoc help. It is an on-going relationship of learning, dialogue and challenge. One can deduce from all these definitions above that mentorship is a personal developmental relationship in which a more experienced or more knowledgeable person which in this study are Chief Lecturers, help to guide the less experienced and less knowledgeable person, which who are young or newly employed Lecturers .

This cordial relationship between the mentor and the mentee with the aim of assisting the mentee to grow in the line of business if effectively applied in the school system may yield result that is capable of maintaining effective school administration in Nigeria (Ayodeji, I.O and Adebayo, L. F. 2015). This is because, teaching has always been described as 
a multifaceted, and complex task that requires guidance from experience or senior colleagues. Conventional Wisdom among Educators, (2011) outlines the concern that new teachers are poorly introduced to the profession, resulting in a loss of the best and the brightest among these teachers. In other words, mentoring in colleges setting could be likened to maintaining and facilitating professional growth among academia

Therefore, for Colleges of Education to fulfil this mentoring role to their subordinates (assistant's lecturers to lecturer ii), they have to create conditions which promote the growth and development of these subordinates within their colleges or schools. These can be achieved by exposing mentee to instructional leadership. Research work Lecturers could be delegated to duties that promote career growth of mentee (Flath, 2000).

Despite the values underpinning mentoring in academic such as increasing satisfaction and retention rate to members of school organisation, increasing self-confidence, professional growth developing competence, encouraging collaboration and not competition among members of an organization, Colleges of Education in Cross River State Nigeria seems to have ignored mentoring in school administration. Several factors that have been found to account for this ugly state of affairs include, inability of young academia willingness to follow, due to the drive quick riches, their inability to manage personnel and to ensure good school community partnership in schools. Likewise Inability to support subordinates professional growth and inability to mentor subordinates on school discipline by school administrator because of godfatherism have been attributed to be the most critical. The present study therefore explores Mentoring and careering development academia in College of Education in Cross River state Nigeria

\section{Research Questions}

The following research question was formulated to guide the study

To ascertain if mentoring is in practices in Colleges of Education in Cross River state Nigeria

\section{Hypothesis}

Ho1: There is no significant difference between the mean rating scores of Federal and State

Academia to the extent of mentoring relationships among academic Staff.

$\mathrm{Ho}_{2}$ : There is no significant difference between the mean rating scores of male and female

lecturers on challenges experienced by protégés in mentoring relationships.

\section{Methodology}

The study adopted a descriptive survey design. Descriptive survey design is the plan of study which enables the researcher to collect data from a well-defined population and systematically selected segments of the population in order to determine the attributes of the population. This definition is in line with Bowlsbey J. (2002) who defined descriptive surveys as those studies concerned with collecting data and describing in a systematic manner, the characteristic features or facts about a given population. Thus, the researcher deemed it wise to adopt descriptive survey design in carrying out this research work.

The area of the study is the two public Colleges of Education in Cross River state

The population of this study consists of all the 1075 Chief lecturers and young lecturers in the two colleges of educations in Cross River state.

The sample size for this study consisted of all the 56 Chief Lecturers and 514 young Lecturers. This gave a total number of 570 respondents which was used for the study. The whole population was used for the study because of the manageable size.

The instrument for data collection is researcher developed questionnaire titled 'Mentoring and Career Development for Academia Questionnaire' (MCDAQ). The questionnaire has two sections. Section A deals on personal data of the respondents. Section B contains Twelve (12) items structured on mentoring and career development of academia in collages of education in Cross River State. This was presented on a 4-point Likert type scale of Strongly Agreed (SA) (4 points), Agreed (A) (3 points), Disagreed (D) (2 points), and Strongly Disagreed (SD) (1 point). 
The instrument was first validated by three (3) experts: from the Faculty of Education, University of Calabar, Calabar. These experts were requested to review the items in terms of their clarity, the appropriateness of the language and expressions to ensure ambiguity and the relevance of the items to the problem under investigation. The experts made necessary corrections and the corrections were affected by the researchers.

The validated instrument was trial tested with twelve (12) Chief Lecturers and eight (8) Assistant Lecturers from the College of Education Katsina-Ala Benue State, which is not part of the study area to ensure its reliability. To ascertain the internal consistency of the instrument Cronbach's Alpha technique was used for its analysis. Reliability coefficients score of 0.96 . The result indicated that the instrument was reliable and therefore considered appropriate for use.

In analyzing the data, mean $(\bar{X})$ and standard deviation (SD) were used to answer the research questions while test was used to analyse the null hypothesis at 0.05 level of significance. An acceptance level of 2.50 was used for the research questions. Any item with 2.50 levels and above was considered acceptable while any item below 2.50 levels was considered not acceptable.

\section{Results and Discussion}

Research question 1: To ascertain if mentoring is in practices in colleges of education in Cross River state, Nigeria.

Table 1. Mean Ratings of chief lecturers and other lecturers on the practice of mentoring in collages of education in cross River state

\section{Chief Lecturers Other Lecturers}

\begin{tabular}{|c|c|c|c|c|c|c|c|}
\hline S/NO & ITEM DESCRIPTION & Mean & SD & Decision & Mean & SD & Decision \\
\hline 1 & $\begin{array}{l}\text { Joint research, publications, teaching and } \\
\text { conference/workshop attendance }\end{array}$ & 3.09 & 0.78 & Agreed & 3.01 & 0.70 & Agreed \\
\hline 2 & $\begin{array}{l}\text { Provision of academic leadership by senior } \\
\text { members }\end{array}$ & 2.69 & 0.67 & Agreed & 4.04 & 0.72 & Agreed \\
\hline 3 & $\begin{array}{l}\text { Mutual respect and reverence for academic } \\
\text { feats, resolve to share resources and } \\
\text { experience }\end{array}$ & 3.18 & 0.75 & Agreed & 2.60 & 0.66 & Agreed \\
\hline 4 & Junior lecturers are attached to chief lecturers & 3.15 & 0.73 & Agreed & 3.07 & 0.79 & Agreed \\
\hline 5 & $\begin{array}{l}\text { Branding of mentors as spearheads of cliques } \\
\text { and protégés as favoured }\end{array}$ & 2.90 & 0.65 & Agreed & 2.98 & 0.69 & Agreed \\
\hline 6 & Self-withdrawal of junior members & 2.58 & 0.60 & Agreed & 3.13 & 0.77 & Agreed \\
\hline 7 & lack of trust & 2.82 & 0.68 & Agreed & 2.95 & 0.92 & Agreed \\
\hline 8 & $\begin{array}{l}\text { Chief lecturers Monitoring and supporting the } \\
\text { appraisal of young lecturers }\end{array}$ & 3.04 & 0.65 & Agreed & 2.64 & 0.82 & Agreed \\
\hline 9 & $\begin{array}{l}\text { Chief lecturers Appreciate subordinates for a } \\
\text { job well done }\end{array}$ & 3.12 & 0.61 & Agreed & 2.98 & 0.93 & Agreed \\
\hline 10 & $\begin{array}{l}\text { Allowing subordinates express their view } \\
\text { during staff forum }\end{array}$ & 2.60 & 0.59 & Agreed & 2.89 & 0.65 & Agreed \\
\hline 11 & $\begin{array}{l}\text { Management organizes mentoring for newly } \\
\text { employed lecturers } \\
\text { (Group mentoring) }\end{array}$ & 3.16 & 0.76 & Agreed & 3.09 & 0.91 & Agreed \\
\hline 12 & $\begin{array}{l}\text { Newly employed lecturers willingly seek } \\
\text { advice and guidance from } \\
\text { experienced lecturers at any time? (informal } \\
\text { mentoring) }\end{array}$ & 2.73 & 0.62 & Agreed & 3.18 & 0.71 & Agreed \\
\hline
\end{tabular}

Based on the data enumerated above, both chief and other lecturers who responded to the twelve (12) questionnaire items, agreed on that mentoring is in practices in Colleges of Education in Cross River State, Nigeria. The mean ratings of Chief Lecturers and other lecturers demonstrated this agreement. The cluster mean of 2.92 and 2.94 were calculated for Chief Lecturers and other lecturers respectively. Overall Standard Deviation of 0.81 and 0.71 were also calculated. This proves their agreement on the existence of mentoring in colleges of education in Cross River state, Nigeria.. 


\section{Hypothesis one}

Table 2 There is no significant difference between the mean rating scores of federal and state academia to the extent of mentoring relationships among academic staff.

\section{Status N Mean SD DF t Sig Dec}

Chief I $562.680 .83568-2.550 .01 \mathrm{~S}$

Lecturers 5142.990 .87

Decision Rule: If the mean is more than 0.05, it implies that the hypothesis is not accepted or is rejected, but if the calculated value is less than or equal to 0.05 , it implies that the hypothesis is accepted. Therefore since the T-cal is 2.55 which is greater than the 0.05 level of significance the null hypothesis is not accepted. There is no significant difference between the mean rating scores of federal and state colleges academia on the extent of mentoring relationships among academic staff.

Table 3 There is no significant difference between the mean rating scores of male and female lecturers on challenges experienced by protégés in mentoring relationships.

\section{Status N Mean SD DF t Sig Dec}

Male $563.340 .69568-1.150 .25 \mathrm{NS}$

Female 5143.440 .64

Decision Rule: If the mean is more than 0.05, it implies that the hypothesis is not accepted or is rejected, but if the calculated value is less than or equal to 0.05 , it implies that the hypothesis is accepted. Therefore since the T-cal is 1.15 which is greater than the 0.05 level of significance the null hypothesis is not accepted. There is no significant difference between the mean rating scores of male and female academia on the challenges they face.

\section{Discussion of finding}

Through the reactions of the respondents on research question one, it was established that the Colleges of Education in Cross River state practice mentoring as: Joint research, publications, teaching and conference/workshop attendance, Mutual respect and reverence for academic feats, resolve to share resources and experience Junior lecturers are attached to chief lecturers, Chief lecturers Monitoring and supporting the appraisal of young lecturers and Chief lecturers Appreciate subordinates for a job well done

This finding is in consonance with Okurame, (2008) who noted that mentoring has recently been revived in Nigerian universities as there is a growing concern about raising academic standards and a desire for Nigerian universities to compete favourably with their counterparts in other parts of the world.

The result of the test of hypothesis (1) further buttressed this findings because There is no significant difference between the mean rating scores of Federal and State academia to the extent of mentoring relationships among academic staff. The study discovered the fact that there is mentoring relationships among academic staff in both Federal and State Colleges of Education, which significantly affected the professional growth of the academia. This confirms the views of (Kilbung Gary, M. 2002). The only means through which academic members in the faculty could benefit from the relationship is therefore through good mentoring. Faculty administrators who may wish to establish mentor/protégé relationships are therefore confronted with the task of ensuring that these partnerships are not only formed but are effective and satisfying. With reference to second research hypothesis, which seeks to determine if there is no significant difference between the mean rating scores of male and female lecturers on challenges experienced by protégés in mentoring relationships. The findings of hypothesis two revealed that female Lecturers experience challenges on protégés in mentoring relationships which is largely due to female Chief Lecturers. These respondents agreed with the views of (Okurame, 2007) and noted that in the Nigerian setting, male mentors provide low levels of psychosocial functions compared to female mentors. It should not be a surprise that psychosocial functions were low. At the same time, the setting of the present study could be adduced as reasons for the low level of psychosocial functions in identified relationships. 
Supporting this views Isiugo-Abanihe U. C (2007) suggests that power disparity in society at large creates a conflict in male mentor-female protege pairs) when the purpose of the relationship is to foster development and achievement that removes the original disparity. Nevertheless, there is an evidence that male mentors had a more positive impact on their female proteges' careers than on their male proteges' careers.

\section{Conclusion}

This study has shown that mentoring plays an important role in the career development of academia in Colleges of Education in Cross River State, Nigeria and that mentoring in these Colleges of Education have some challenges which affect he female folk more.

\section{Recommendations}

Based on the findings of the study, the following recommendations are made:

An enlightenment campaign should be done by the various Management of the Colleges of Education as a criterion for promotion

Newly employed lecturers should willingly seek advice and guidance from experienced lecturers at all time (Informal mentoring) as it boosts their academic development.

Recognise and provide discipline -oriented career counsellors who are other staff and offer up to date information on the benefit of mentoring

Topics relevant to mentorship with professional standard, ethnical values balancing career or post doctorial programmes should be introduces as Lecture series in Colleges

Annual seminars on latest employment trends and internship opportunities should be introduced in staff forum activities.

Create an institutional award for a distinguished mentor in annual staff programmes.

Track the progress of mentorship of staff through the provision of information about career experiences of young staff

\section{Reference}

[1] Ayodeji, I. O. and Adebayo, L. F. (2015). Role of mentorship in business development in Nigeria: Global Journal of Humanity and management, Vol. 3 No 3 pp 17-38

[2] Barth, R. (2011). Improving school from within. San Francisco: Josey Bass.

[3] Baugh, S. G. and Sullivan, S. E. (2005), Mentoring and career development, Career Development International, Vol. 10 No. 6/7, pp. $423-428$.

[4] Bowlsbey, J (2002). Career development interventions in the 21st Century. Columbus OH: Merril Prentice Hall.

[5] Dancer, J. A. (2003), Mentoring in healthcare: theory in search of practice? Clinician in Management, Vol. 12, pp. $21-31$.

[6] Ezenwa (2011). Constraints of effective school administration. Nsukka: Totan Publishers.Gary, D. (2000), Human Resource Management, New Jersey River: Prentice Hall.

[7] Isiugo-Abanihe, U. C. (2007), Staffing. Faculty of the Social Sciences, University of Ibadan, 2007/2008 prospectus (pp. 6). Ibadan: The Dean's office, Faculty of the Social Sciences.

[8] Kilbung, Gary M. (2002). Issues in mentoring from the perspective of the centre for excellence in mentoring. A paper presented at the Oregan Association of Teacher Education Conference 2002-part land Oregan Murray, M. (1991). Benothde myths and magic of mentoring. San Francisco: Jossey- Bass Publishers.

[9] Olowu, A. A, (2013). Mentoring ; A key issue in human Resource Management. ile ife - ife Centre for psychological studies services 
[10] Okurame, D. E. and Balogun, S. K. (2005), Role of Informal Mentoring in the Career Success of First-line Bank Managers: a Nigerian case study, Career Development International, Vol. 10, No. 6/7, pp. 512 - 521.

[11] Okurame, D. E. (2006), Career outcomes of job experience and gender occurrence of mentoring, Ibadan Journal of the Social Sciences, Vol. 4, No. 2, pp. 111 - 119.

[12] Okurame, D. E. (2007), Perceived mentoring functions: Does mentor's gender matter? Women in Management Review, Vol. 22 No. 5, pp. 418 - 427.

[13] Payne, S. (2006, accessed 12/12/2006), Mentoring a smart business decision, research shows, http://communications.tamu.edu/newsarchives/05/020705-10.html

[14] Spencer, C. (2010). Mentoring made easy; a. practical guide. Retrieved from http://www.eco.gov.au/careers/mentor.htm.

[15] Ugwuanyi, R.N.C. (2011). Mentoring as a tool for capacity building in libraries. Nigerian Library Link, a journal of Library and information Science, 9 (1\&2) 97-1 05.

[16] Young A. M, Cady .S, and Forom M.I. (2006) Demystifying gender difference in mentoring, theoretical perspectives and challenges for future research in gender mentoring and Human Resource Development 5 148176 